\title{
Aspects of heat inactivation of foot-and-mouth disease virus in milk from intramammarily infected susceptible cows
}

\author{
By P. W. DE LEEUW, J. W. A. TIESSINK AND J. G. VAN BEKKUM \\ Central Veterinary Institute, Virology Department, 39 Houtribweg, \\ 8221 RA Lelystad, The Netherlands
}

(Received 8 February 1979)

\section{SUMMARY}

In skim milk obtained from susceptible cows after intramammary and intravenous inoculation (primary infected milk), foot-and-mouth disease (FMD) virus type $\mathrm{O}_{1}$ was slower inactivated by heat treatment than virus that had been added to pre-exposure skim milk.

Residual virus infectivity in heated primary infected milk was more efficiently detected in bovine thyroid cell cultures than in secondary pig kidney $\left(\mathrm{PK}_{2}\right)$ cell cultures.

Untreated primary infected milk was found to inhibit both FMD-virus and vesicular stomatitis virus plaque formation in $\mathrm{PK}_{2}$ cells, suggesting the presence of interferon. The results of further tests confirmed that the interfering activity in unheated primary infected milk was indeed caused by an interferon.

Interferon excretion in primary infected milk was investigated using a series of milk samples from three cows. Maximum interferon titres were found after $24 \mathrm{~h}$, coinciding with or shortly after the first virus excretion peak. The results are discussed with particular reference to the use of primary infected milk in studies of the thermal inactivation of FMD-virus.

\section{INTRODUCTION}

Excretion of foot-and-mouth disease (FMD) virus in milk of infected susceptible cows is well documented (Lebailly, 1920; Burrows, 1968). FMD-virus infected milk is a major potential hazard in the control of FMD in areas with a fully susceptible livestock population (Dawson, 1970; Hedger \& Dawson, 1970). Although evidence suggesting direct involvement of milk products prepared from infected milk in a FMD field outbreak has not been reported, the potential risks have been recognized by animal health authorities, nationally and internationally. Consequently, the effect of milk processing procedures on FMD-virus infectivity has been studied extensively.

Most of these studies were undertaken using milk to which virus was added (Kästli \& Moosbrugger, 1968; Sellers, 1969). The use of FMD-virus infected milk obtained after intravenous and udder inoculation was introduced recently (Hyde, Blackwell \& Callis, 1975; Blackwell \& Hyde, 1976; Dhennin \& Labie, 1976). 
In the course of a study of the thermal inactivation of FMD-virus in similarly obtained infected milk, we could confirm the observations of Hyde et al. (1975) that cell cultures were far less sensitive for the detection of residual virus infectivity than susceptible cattle. In addition, an 'autointerference' phenomenon was observed when low dilutions of untreated infected milk were plated. These observations led to a study of the interfering mechanisms in untreated and heated infected milk. The results of this study are presented in the present report.

\section{Viruses}

\section{MATERIALS AND METHODS}

F'MD-virus, type $O_{1}$, strain Weerselo $(O W)$ was used. This strain was isolated in The Netherlands in the 1966 epizootic and had received three intradermolingual passages in susceptible steers.

In some experiments FMD-virus type $\mathrm{O}_{1} \mathrm{BFS}$ from the 1967 outbreak in the U.K. was used. This strain was grown in surviving cattle tongue epithelium in suspension (Frenkel, 1964).

Vesicular stomatitis virus (VSV), strain Indiana, was grown in secondary pig kidney cell cultures.

All virus suspensions were stored in small volumes at $-70^{\circ} \mathrm{C}$.

\section{Virus concentration and purification}

$\mathrm{O}_{1} \mathrm{BFS}$ virus was concentrated 200 -fold by two consecutive PEG precipitations and purified by isopicnic banding in $\mathrm{CsCl}$ as described by Barteling et al. (1979). The purified virus was dialysed against $0.05 \mathrm{~m} \mathrm{Na-phosphate} \mathrm{buffer} \mathrm{(PB)} \mathrm{con-}$ taining $0 \cdot 2 \mathrm{M}-\mathrm{NaCl}, \mathrm{pH} 7 \cdot 5$, and stored at $4{ }^{\circ} \mathrm{C}$ in the presence of $0 \cdot 1 \%$ sodium azide.

\section{Cell cultures and plaque titrations}

The following cell cultures were used: secondary pig kidney $\left(\mathrm{PK}_{2}\right)$, secondary bovine embryo kidney $\left(\mathrm{BEK}_{2}\right)$, 15th passage of sheep choroid plexus $(\mathrm{PC})$, primary duck embryo fibroblast (DEF), 27th passage of mink kidney, 5th passage of human embryo lung (kindly provided by Dr D. Herderscheê, Path. Anat. Bact. Lab., Deventer, The Netherlands), BHK 21 (approximately 50th passage) and rabbit kidney, RK13 (160th passage). The cells were grown in $6 \mathrm{~cm}$ disposable plastic petri dishes in a $5 \% \mathrm{CO}_{2}$ atmosphere. The growth medium used was Earle's MEM (EMEM) with $10 \%$ calf serum (CS) and antibiotics, except for $\mathrm{PK}_{2}$ cells $(10 \%$ lamb serum (LS)), PC cells (15\% LS) and DEF cells (medium 199 with $5 \%$ CS). Maintenance medium consisted of growth medium with 2-3\% serum. All sera were free from antibody against FMD-virus and VSV.

Plaque titrations were carried out in monolayers 1 to 3 days after reaching confluence, using two petri dishes for each dilution.

Virus titres are expressed as plaque forming units (p.f.u.) per ml.

In addition, primary bovine embryo thyroid (BTY) cell cultures were used. 
They were grown in tubes according to the method described by Plowright \& Ferris (1961) and were used after 7 to 14 days. Monolayers were checked twice daily for cytopathic effect (CPE). From negative cultures the supernatant was inoculated onto fresh monolayers. Samples were considered negative for FMDvirus if no CPE developed in $72 \mathrm{~h}$.

\section{Animals, inoculation and sampling}

Five dairy cows and two steers were used, all susceptible to FMD. The cows were 4 to 7 years old and the steers approximately 18 months. The cows were in middle to late lactation; a mild mastitis was diagnosed by milk cell counting in one of them. This cow was treated with a long-acting antibiotic preparation two weeks before the beginning of the experiments. Milking was done by hand twice daily unless stated otherwise. Normal dairy hygiene was practised in respect of udder washing and disinfection.

The cows were inoculated intramammarily and intravenously by introducing $10 \mathrm{ml}$ of an $\mathrm{OW}$-virus suspension, containing $10^{7}$ p.f.u., into the milk sinus of each quarter using a teat cannula, and injecting the same amount into the jugular vein. FMD-virus-containing milk obtained after intramammary and intravenous inoculation is referred to as primary infected milk.

In addition, milk samples were obtained from two intranasally infected FMD susceptible cows used in another experiment (de Leeuw, van Bekkum \& Tiessink, 1978). These cows were inoculated by slow instillation of $2.5 \mathrm{ml}$ of an $\mathrm{OW}$-virus suspension containing $10^{7}$ p.f.u. per $\mathrm{ml}$, into the ventral part of each nasal passage as described by McVicar \& Sutmoller (1976). Milk samples were obtained twice daily the first ten days post inoculation (p.i.). All milk samples were used within $3 \mathrm{~h}$ of collection and/or stored in $20 \mathrm{ml}$ volumes at $-70^{\circ} \mathrm{C}$. All tests were carried out with skim milk obtained by centrifugation for $20 \mathrm{~min}$ at $2500 \mathrm{rev} . / \mathrm{min}$, removal of the cream layer and collection of the skim milk part without disturbing the pelleted debris. Milk samples were assayed for virus by plaque titration using $\mathrm{PK}_{2}$ cells. The steers were used for an innocuity test; they received $5 \mathrm{ml}$ of heated milk intradermolingually (i.d.l.) and $25 \mathrm{ml}$ intramuscularly.

All animals were observed twice daily for symptoms of FMD, rectal temperatures were taken at the same time. If FMD developed vesicle epithelium was harvested for typing by complement-fixation.

\section{Heat treatment}

Milk samples were heated either in ampoules or in capillary tubes. Volumes of $1.5 \mathrm{ml}$ in sealed $2 \mathrm{ml}$ borosilicate glass ampoules* were heated rapidly to the desired temperature in a water bath held at a higher temperature. When the desired temperature was nearly reached, as indicated on a recorder connected to a thermocouple inserted in a control ampoule, the ampoules were transferred to a water bath of the correct temperature $\pm 0.25^{\circ} \mathrm{C}$. Using this method, the time needed to warm up the contents to the required temperatures could be kept between 30 and 45 seconds. 
Borosilicate glass capillary tubes (length $10 \mathrm{~cm}$, outer diameter $1.9-2 \cdot 2 \mathrm{~mm}$, inner diameter $1.6-1.9 \mathrm{~mm}$, kindly provided by The Netherlands Institute for Dairy Research, Ede, The Netherlands) were filled with volumes of approximately $0.1 \mathrm{ml}$, leaving an air chamber on both sides of 7-10 $\mathrm{mm}$. After flame-sealing they were fitted in a metal rack designed for this purpose so that they stood free of each other, and completely immersed in a water bath of the desired temperature for a given time.

No allowance was made for the time the contents needed to reach that temperature. The lag in heat penetration in this system can be estimated to be 2-4 seconds (Stern, Herlin \& Proctor, 1952).

After heating, both ampoules and capillary tubes were immediately cooled in an ice bath.

\section{Tests for interferon}

All tests were done with skim milk samples of which the $\mathrm{pH}$ had been lowered to $2 \cdot 0$ by addition of $1 \mathrm{~N}-\mathrm{HCl}$ and restored to $7 \cdot 2$ with $1 \mathrm{~N}-\mathrm{NaOH}$ after $24 \mathrm{~h}$ at $4^{\circ} \mathrm{C}$.

VSV plaque reduction test. This test was carried out according to standard methods. The interferon titre of a sample is expressed as the $\log _{10}$ of the reciprocal of the dilution giving $50 \%$ reduction in the number of plaques in treated (milk sample) cell cultures as compared with that observed in 'buffer-treated' controls.

Ultracentrifugation and dialysis. Milk samples were centrifuged for $90 \mathrm{~min}$ at $32000 \mathrm{~g}$ to remove the casein. The resulting clear milk serum was centrifuged for $90 \mathrm{~min}$ at $120000 \mathrm{~g}$ and the supernatant collected.

A volume of $5 \mathrm{ml}$ was then dialysed against one litre of EMEM for $24 \mathrm{~h}$ at $4{ }^{\circ} \mathrm{C}$ with four changes of the medium.

Trypsin treatment. Volumes of $0.5 \mathrm{ml}$ of milk were incubated with equal volumes of a $0.5 \%(w / v)$ trypsin* solution in PBS for $1 \mathrm{~h}$ at $37{ }^{\circ} \mathrm{C}$. The action of the enzyme was stopped by addition of $2.5 \mathrm{ml}$ of a $0.15 \%(\mathrm{w} / \mathrm{v})$ solution of soybean trypsin-inhibitor* in PBS.

Actinomycin D pre-treatment of cell cultures. BEK $_{2}$ cell monolayers were washed with EMEM and incubated with $2 \mathrm{ml}$ volumes of EMEM containing $2 \% \mathrm{CS}$ and $1 \mu \mathrm{g}$ actinomycin $\mathrm{D} \dagger$ for $1 \mathrm{~h}$ at $37^{\circ} \mathrm{C}$, according to Levine (1964). After a threefold rinse, the monolayers were incubated with $2 \mathrm{ml}$ volumes of a milk sample diluted 1/10 in EMEM for $6 \mathrm{~h}$ at $37^{\circ} \mathrm{C}$. A further threefold rinse was followed by inoculation of $0.5 \mathrm{ml}$ volumes of a VSV suspension containing 100 p.f.u. The virus was allowed to adsorb for $1 \mathrm{~h}$ at $37^{\circ} \mathrm{C}$, the monolayers were washed again and maintenance medium was added. Samples were taken after 16, 24, 40 and $48 \mathrm{~h}$ of incubation at $37^{\circ} \mathrm{C}$, frozen at $-70^{\circ} \mathrm{C}$, and later titrated by plaque assay in $\mathrm{PK}_{2}$ cell cultures. The experiments were done using triplicate cultures and three controls: cells treated with actinomycin D only, with the diluted milk sample only, and not treated with either.

* Sigma Chemical Company, Saint Louis, U.S.A.

$\dagger$ Merck, Darmstadt, West Germany. 


\section{EXPERIMENTS AND RESULTS}

The thermal inactivation rate of FMD-virus in primary infected skim milk was studied using the $12 \mathrm{~h}$ p.i. milk samples from cows nos 1 and 2 . With the sample of cow no 1 , which had been stored at $-70^{\circ} \mathrm{C}$, three different experiments were carried out at $56{ }^{\circ} \mathrm{C}$. In each experiment similarly stored pre-exposure skim milk of the same cow to which $O_{1}$ BFS virus had been added at a ratio of 1:10 before heating, was included for comparison. The fresh milk sample of cow no 2 was used for experiments at $56,58,60,63$ and $72{ }^{\circ} \mathrm{C}$; the experiments at 56 and $58{ }^{\circ} \mathrm{C}$ were repeated using the same batch of cells after the sample had been frozen at $-70{ }^{\circ} \mathrm{C}$. The $\mathrm{pH}$ of the milk was adjusted to 7.4 with $1 \mathrm{~N}-\mathrm{NaOH}$ before heating in capillary tubes. All samples were titrated by plaque assay in $\mathrm{PK}_{2}$ cell cultures. In addition, samples heated at or above $60^{\circ} \mathrm{C}$ were inoculated undiluted onto BTY cell monolayers.

In primary infected milk FMD-virus was inactivated more slowly than virus that had been added to milk, in particular during the first minutes of heating at $56{ }^{\circ} \mathrm{C}$. Thereafter the rate of inactivation was approximately the same (Fig. $1 \mathrm{~A}$ ). As expected the inactivation rate increased at higher temperatures. If primary infected milk had been stored at $-70^{\circ} \mathrm{C}$ before heating, the rate of virus inactivation during the first minutes was enhanced compared with that in fresh samples (Fig. 1B). Plaques were not observed in $\mathrm{PK}_{2}$ cell monolayers inoculated with milk samples heated for $1 \mathrm{~min}$ or more at $60^{\circ} \mathrm{C}$ or at higher temperatures. In BTY cell cultures infectivity was recovered from samples heated for up to $2 \mathrm{~min}$ at $60{ }^{\circ} \mathrm{C}$ and up to $1 \mathrm{~min}$ at $63^{\circ} \mathrm{C}$ (Table 1). Infectivity was not recovered in cell cultures from samples heated at $72^{\circ} \mathrm{C}$. However, the same milk sample of cow no. 2, heated for 0.5 min at $80^{\circ} \mathrm{C}$, caused FMD in two inoculated steers in $48 \mathrm{~h}$.

In the experiments described above it was noted that CPE or plaques did not develop in $\mathrm{PK}_{2}$ cell cultures inoculated with dilutions of less than 1/100 of untreated or heated primary infected milk, whereas after inoculation with higher dilutions CPE or isolated plaques were observed. In addition, CPE in inoculated BTY cell monolayers developed slowly: with most positive samples it only became distinct after a sub-culture had been made.

To examine these observations more closely, $\mathbf{P K}_{2}$ cell cultures were incubated with unheated or heated primary infected milk before inoculation with approximately 100 p.f.u. VSV or $\mathrm{O}_{1}$ BFS virus. FMD plaques did not develop in any of the treated monolayers, but increasing numbers of VSV plaques were observed in cultures treated with milk heated at successively higher temperatures (Table 2). Thus, either the primary infected milk contained two interfering substances, of which one was affected by heat and was effective only against VSV, or an additional interfering principle was produced by heat treatment which was merely effective against FMD-virus. The possibility that the latter might be of viral origin, was tested by mixing infective VSV or FMD-virus with heated purified FMD-virus. The numbers of plaques found in cell cultures inoculated with mixtures of heated and untreated FMD-virus, in each experiment were less than those observed in the corresponding controls provided the titres of the purified virus suspensions 


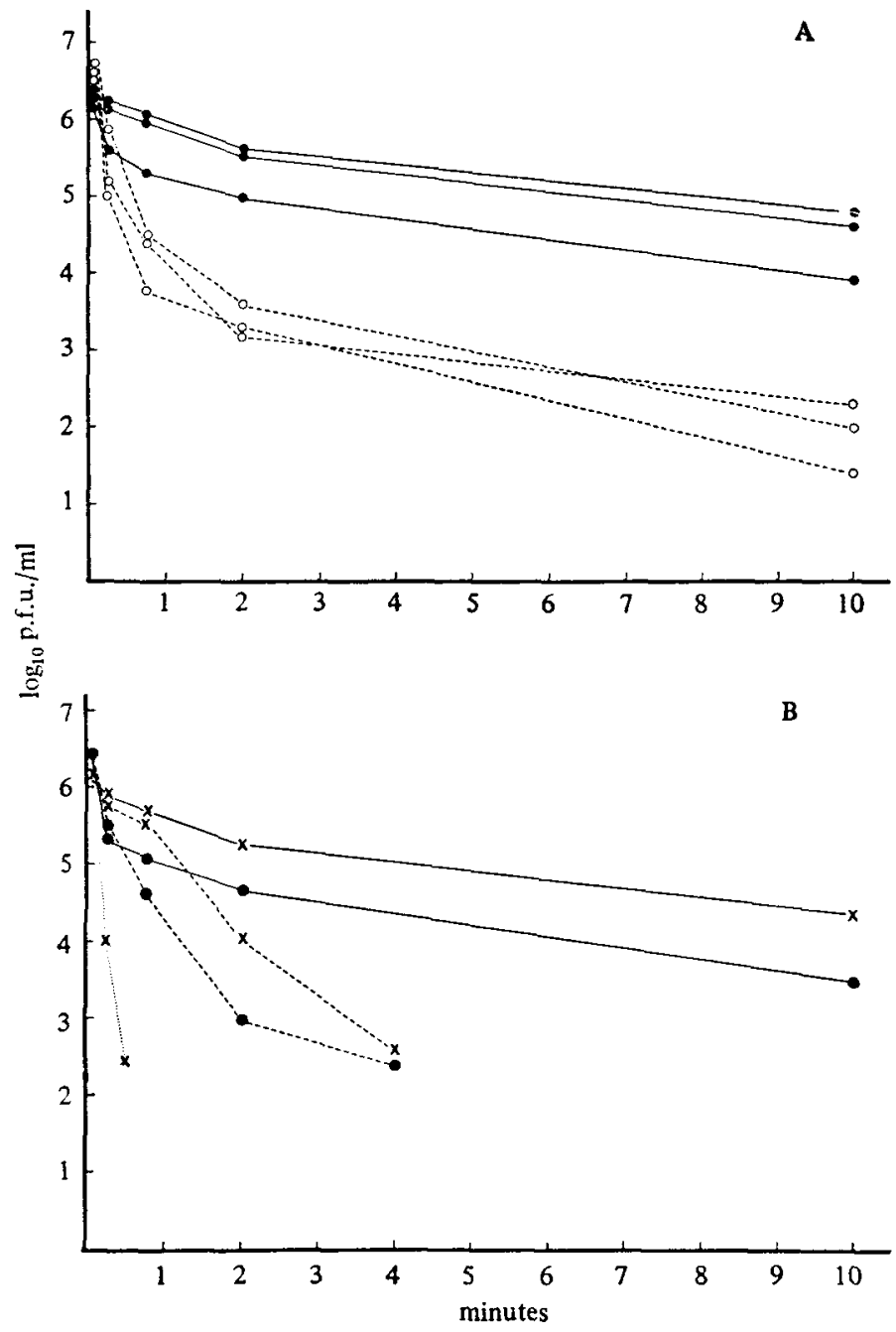

Fig. 1. Thermal inactivation curves of FMD-virus type $O_{1}$ in skim milk, pH 7.4. (A) $56{ }^{\circ} \mathrm{C}$, repeated experiments with a milk sample from cow no. 1 obtained $12 \mathrm{~h}$ after intravenous and intramammary inoculation (-O) and with virus diluted $1: 10$ in pre-exposure milk of the same cow $\left(\mathrm{O}_{-}-\mathrm{O}\right)$. Infected and pre-exposure milk stored at $-70^{\circ} \mathrm{C}$. (B) One experiment at $56(-), 58(---)$ and $60^{\circ} \mathrm{C}$ $(\ldots)$, before $(-x-)$ and after $\left.(-)^{-}\right)$freezing at $-70^{\circ} \mathrm{C}$ with a similarly obtained infected milk sample from cow no. 2 .

were $10^{7.7}$ or higher before heating (Table 3). The numbers of VSV plaques found were approximately the same as in the corresponding controls.

The presence of interfering substances in primary infected milk was investigated using milk samples from cows nos 3, 4 and 5. These cows were febrile one day p.i. and their milk production was reduced to $50-70 \%$ of the pre-exposure values. The milk was slightly yellow and an increased cell sediment was found. Only cow no. 5 clearly had mastitis; the udder was hot and tender and the milk contained obvious clots. After the first day temperatures returned to near normal, only 
Table 1. Recovery of FMD-virus infectivity from heated primary infected skim milk $\mathrm{pH} \mathbf{7 \cdot 4}$ in cell cultures

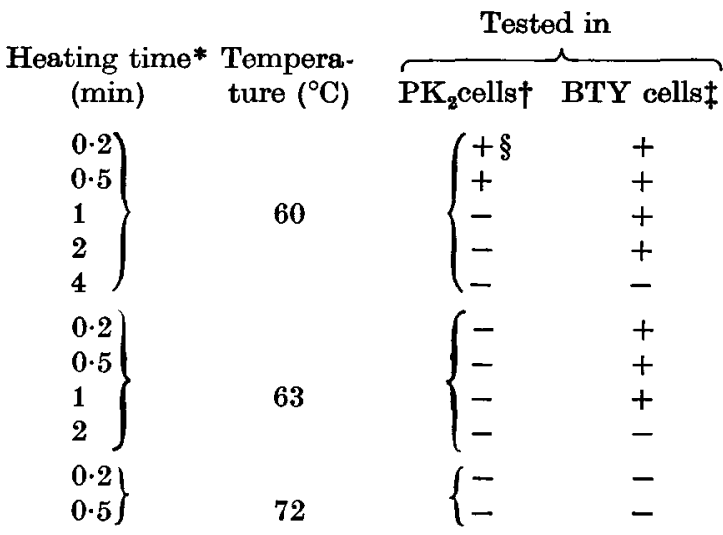

* Milk obtained $12 \mathrm{~h}$ p.i., FMD-virus titre $10^{8.2}$ per ml; heated in sealed glass capillary tubes.

$\dagger$ Plaque assay in secondary pig kidney cell monolayers.

$\$$ Monolayers of bovine embryo thyroid cells; results indicated include one subculture.

$\S+$ = infectivity recovered; $-=$ negative.

Table 2. Inhibition of VSV and $F M D$-virus plaque formation in $P K_{2}$ cells by prior incubation of the cells with untreated and heated primary infected skim milk

$\begin{array}{cccc}\text { Milk sample } & \begin{array}{c}\text { Heated for } \\ 2 \text { min at } \\ \left({ }^{\circ} \mathrm{C}\right)\end{array} & \text { VsV } & \text { FMD-virus } \\ \text { Infected* } & -\dagger & 0 & 0 \\ & { }^{\dagger} & 3 \ddagger & 0 \\ & \mathbf{6 4} & 19 & 0 \\ \text { Control\$ } & \mathbf{7 4} & \mathbf{5 4} & 0 \\ & - & \mathbf{9 7} & \mathbf{8 6}\end{array}$

* Milk sample obtained $12 \mathrm{~h}$ p.i.; cells incubated with skim milk for $1 \mathrm{~h}$ at $37^{\circ} \mathrm{C}$ before challenge with VSV or FMD-virus.

$\dagger$ Unheated.

¥ Mean number of plaques in duplicate cultures.

$\S$ Pre-exposure milk of the same cow.

cow no. 3 had fever again on days 3 and 4. Nevertheless, symptoms of FMD were not observed in this cow during an observation period of 4 weeks. Cows nos 4 and 5 had generalized FMD lesions on day 4. The $\mathrm{pH}$ of the milk was raised 16-24 h p.i. (7.0-7.4) but returned to normal values on day 2.

All milk samples obtained were titrated for FMD-virus by plaque assay and for interferon content by the VSV plaque reduction test.

The FMD-virus excretion curves were biphasic: a first peak occurring 16 to $24 \mathrm{~h}$ p.i. and a second peak on day 3 or 4 . Samples obtained on day 7 were all negative (Fig. 2). 
Table 3. Inhibition of plaque formation by mixing infective with heated purified FMD-virus suspensions

\begin{tabular}{|c|c|c|c|c|}
\hline \multirow{2}{*}{$\begin{array}{l}\text { Purified } \\
\text { virus titre } \\
\left(\log _{10}\right. \\
\text { p.f.u. } / \mathrm{ml})\end{array}$} & \multicolumn{2}{|c|}{$\begin{array}{l}\text { Heated in buffer* } \\
\text { expt. no }\end{array}$} & \multicolumn{2}{|c|}{$\begin{array}{l}\text { Heated in skim milk } \\
\text { expt. no }\end{array}$} \\
\hline & 1 & 2 & 1 & 2 \\
\hline $8 \cdot 7$ & $45 \ddagger$ & 32 & 16 & 14 \\
\hline $7 \cdot 7$ & $102^{\circ}$ & 103 & 56 & 80 \\
\hline $6 \cdot 7$ & 133 & 138 & 89 & 95 \\
\hline$-\S$ & 132 & 137 & 82 & 100 \\
\hline
\end{tabular}

* Purified virus suspensions $\left(\mathrm{O}_{1} \mathrm{BFS}\right)$ heated for $2 \mathrm{~min}$ at $74^{\circ} \mathrm{C}$, and mixed with an equal volume of homologous infective virus.

$\dagger$ Purified virus suspensions mixed 1:10 in pre-exposure skim milk of cow no. 2 before heating and mixing with infective virus.

* Mean number of plaques in triplicate $\mathrm{PK}_{2}$ cell cultures.

$\S$ Controls; infective virus mixed with heated buffer or skim milk. No plaques were found when plating heated purified virus suspensions.
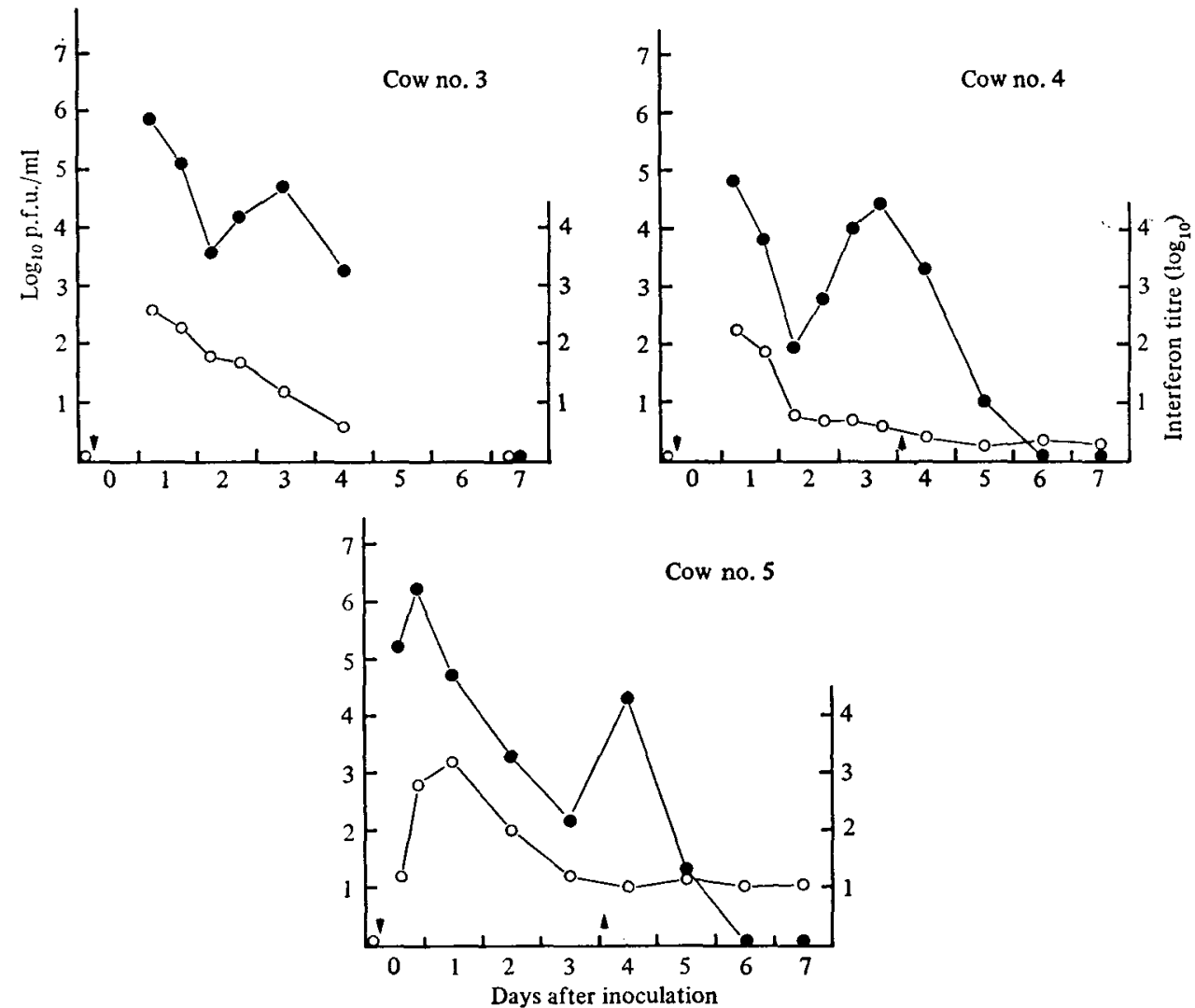

Fig. 2. Virus (-O) and interferon (O-O) excretion in milk of susceptible cows after intramammary and intravenous inoculation with FMD-virus type $O_{1}$. $\downarrow$ inoculation; $\uparrow$ generalization. 
Table 4. Influence of several treatments on the interferon titre of a milk sample obtained $24 h$ after intravenous and intramammary inoculation with FMD-virus, type $O_{1}$

\section{Treatment}

None*

Casein removed by centrifugation

Ultracentrifugation (120000 g, $90 \mathrm{~min}$ )

Ultracentrifugation followed by dialysis

Trypsin-treatment

Heating for $2 \mathrm{~min}$ at

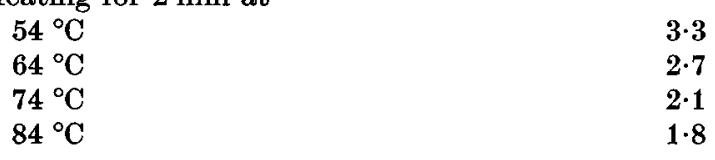

Titre on

$\mathrm{PK}_{2}$ cells

$3 \cdot 3 \dagger$
$3 \cdot 1$
$3 \cdot 0$
$3 \cdot 1$
$<1 \cdot 4$

$3 \cdot 3$
$2 \cdot 7$
$2 \cdot 1$
$1 \cdot 8$

* Skim milk that had been kept at pH 2 for $24 \mathrm{~h}$.

$\dagger$ Titres expressed as the $\log _{10}$ of the dilution causing $50 \%$ reduction of the number of VSV-plaques.

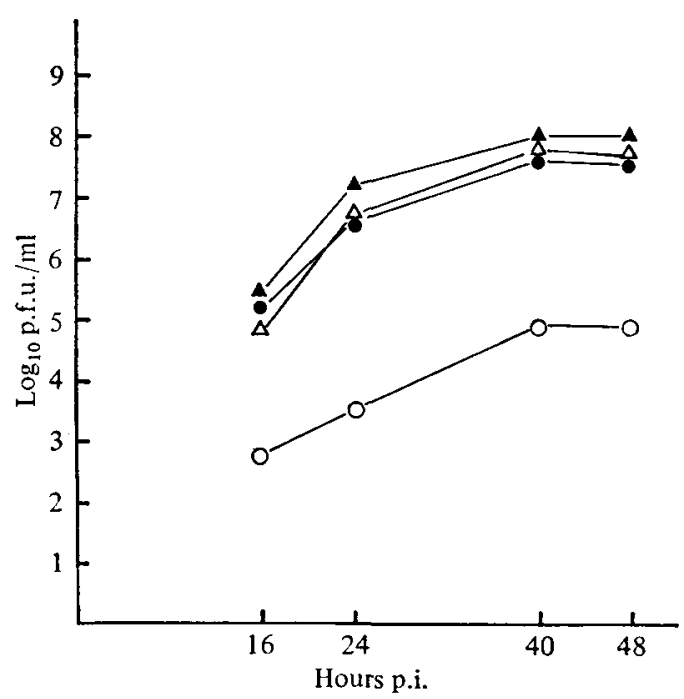

Fig. 3. Effect of actinomycin D on VSV multiplication in $\mathrm{BEK}_{2}$ cells treated with primary infected milk. $\mathrm{O}-\mathrm{O}$, VSV titres of pooled medium of three $\mathrm{BEK}_{2}$ cell cultures, treated with a $1: 10$ diluted milk sample prior to inoculation; $\triangle-\triangle$, idem, but cells pre-treated with actinomycin $\mathrm{D}\left(1 \mu \mathrm{g}, 1 \mathrm{~h}, 37^{\circ} \mathrm{C}\right)$. Controls : $-O$ untreated cells; $\Delta-\Delta$ cells treated with actinomycin $\mathrm{D}$ only.

Interfering activity was found in samples obtained from cow no. 3 on days 1 to 4 and from cow no. 4 on days 1 to 7 . Maximum interferon titres of $2 \cdot 6$ and $2 \cdot 3$ were observed in the first milk samples obtained $24 \mathrm{~h}$ p.i. Cow no. 5, which was sampled more frequently, already had interfering activity in the milk sample obtained $8 \mathrm{~h}$ p.i. The highest titre (3.2) was also observed in the sample taken $24 \mathrm{~h}$ p.i., thereafter the titres decreased until day 4 and then remained at the same level (Fig. 2). 


\section{Table 5. Interferon titre of a primary infected milk sample} in cells of different species

\begin{tabular}{llc} 
Species & \multicolumn{1}{c}{ Designation } & $\begin{array}{c}\text { Interferon } \\
\text { titre }\end{array}$ \\
Swine & Secondary kidney & $\mathbf{3 \cdot 2 *}$ \\
Cattle & Secondary embryo kidney & $\mathbf{3 \cdot 2}$ \\
Sheep & Choroid plexus, 15th passage & $>\mathbf{2 \cdot 2}$ \\
Rabbit & RK 13 & $\mathbf{1 \cdot 5}$
\end{tabular}

* Skim milk was used exposed to $\mathrm{pH} 2$ for $24 \mathrm{~h}$; the lowest dilution tested was $1: 10$. No activity was found in hamster, mink, duck and human cell cultures.

Controls for the interferon test consisting of pre-exposure milk samples with and without added $\mathrm{O}_{1} \mathrm{BFS}$ virus, were all negative.

Further characterization of the interfering principle, tests on cell cultures derived from different species, and tests for interferon-inducing activity were all carried out using the milk sample of cow no. 5 obtained $24 \mathrm{~h}$ p.i.

Removal of the casein, ultracentrifugation for $90 \mathrm{~min}$ at $120000 \mathrm{~g}$ or ultracentrifugation followed by dialysis did not cause a significant drop in the interferon titre of the sample. However, trypsin treatment reduced the titre at least a hundredfold (Table 4). Heating for $2 \mathrm{~min}$ at successively higher temperatures caused a gradual decline of the interfering activity. Nevertheless the sample still had a titre of 1.8 after heating for 2 min at $84{ }^{\circ} \mathrm{C}$ (Table 4).

Treatment of $\mathrm{BEK}_{2}$ cells with actinomycin $\mathrm{D}$ before incubation with a $1 / 10$ dilution of the milk sample completely neutralized the effect of the milk sample on VSV multiplication (Fig. 3).

The interfering activity of this milk sample with VSV plaque formation in cells derived from different species is shown in Table 5 .

Approximately the same interferon titres were found in porcine, bovine and ovine cells; in rabbit cells the activity was considerably less. No interfering activity was found in the 1/10 diluted sample in hamster, mink, duck and human cell cultures.

As a possible test for interferon-inducing activity of the milk sample, the following experiment was carried out.

Confluent $\mathrm{PK}_{2}$ cell monolayers were incubated with $2 \mathrm{ml}$ volumes of the undiluted skim milk sample for 1 or $24 \mathrm{~h}$ at $37^{\circ} \mathrm{C}$. After a threefold rinse with PBS, $6 \mathrm{ml}$ of maintenance medium was applied to each culture and incubation was continued for $20 \mathrm{~h}$. The medium of triplicate cultures was then collected, pooled, exposed to $\mathrm{pH} 2$ and titrated for interfering activity.

Interferon titres of $0.6-0.7$ were found in the pooled maintenance medium of cultures incubated with the untreated primary infected milk sample whereas negative results were obtained with pre-exposure milk samples, either after 1 or $\mathbf{2 4} \mathrm{h}$ of incubation.

Heat treatment of the primary infected milk sample for 2 min at 64 or $74{ }^{\circ} \mathrm{C}$ or exposure to $\mathrm{pH} \mathrm{2,} \mathrm{reduced} \mathrm{the} \mathrm{interferon} \mathrm{inducing} \mathrm{activity} \mathrm{to} \mathrm{levels} \mathrm{undetectable}$ by this method. 
The intranasally infected susceptible cows developed FMD lesions on day 4, coinciding with the first time virus was detected in their milk. They excreted virus during 3-4 days but a distinct pattern was not observed; the titres remained between $10^{1.2}$ and $10^{2.7}$ (de Leeuw et al. 1978).

Interfering activity could not be detected in any of the milk samples; only one sample obtained on day 4 had a doubtful titre of $0 \cdot 3$.

\section{DISCUSSION}

Burrows et al. (1971) studied several aspects of intramammary inoculation of susceptible cows with FMD-virus. Our results showing development of FMD lesions 4 days p.i. and biphasic virus excretion curves in milk are in general agreement with the results of the above mentioned authors and with those of others (Hyde et al. 1975; Blackwell \& Hyde, 1976). Blackwell \& Hyde (1976) too reported that one of their intramammarily inoculated susceptible cows did not develop any signs of F'MD although a significant virolactia did occur.

The interfering activity of primary infected milk, described in this report, may explain the results reported by Burrows et al. (1971). They observed that virus could not be recovered in cell cultures from the milk of three out of four cows, inoculated intramammarily with $\mathrm{O}_{1}$ BFS virus, between 32 and $56 \mathrm{~h}$ p.i., and that virus inhibitory activity was found in the sera of these animals at the same time.

The results of the interferon tests that were carried out (Figs. 2 and 3, Table 4) strongly suggest that the observed interfering activity in primary infected milk is indeed caused by an interferon (Lockart, 1973). High interfering activity in cells from heterologous species (Table 5) has also been reported by others for interferons derived from bovine as well as other species (Rinaldo et al. 1976; Gresser et al. 1974; Nagono \& Maehara, 1975); therefore 'species specificity' is no longer a requisite for considering 'interference' as due to interferon (Lockart, 1973).

In some pre-exposure milk samples we observed a similar antiviral activity as described by Matthews et al. (1976). It was much less effective than the interfering activity described in this report and does not meet the interferon criteria, for example in that it is only active if milk and virus are added to cells at the same time. To our knowledge there are no reports in the literature which point to the bovine mammary gland as an effective interferon producing organ.

Interfering activity could not be detected in the medium of $\mathrm{PK}_{2}$ cell cultures after incubation with primary infected milk that had been exposed to $\mathrm{pH} 2 \cdot 0$ or heated for $2 \mathrm{~min}$ at $64^{\circ} \mathrm{C}$. These results suggest that leakage of passively acquired interferon from the cells or detachment from cell membrane receptors (Berman \& Vilcek, 1974) were not responsible for the interfering activity found in the medium after incubation of the cultures with untreated material. Active interferon production of the cells, either induced by non-viral products or by infective virus in the presence of virus inhibiting factors, seems a more likely explanation.

The thermal inactivation curves of FMD-virus in primary infected milk and of virus added to milk (Figs. 1 A, B) all show a rapid initial decline, similar to that 
reported for FMD-virus in buffer (Bachrach et al. 1957). The fact that inactivation curves were difficult to construct at low levels of virus survival can be explained by the interfering activity that remains after heating (Tables 2 and 4). Apart from that, additional interfering activity may be produced by heat treatment (Table 2).

Whether components of viral origin are responsible for this effect could not be ascertained. The titres of purified virus suspensions necessary to obtain strong interference after heating (Table 3) are higher than those observed in primary infected milk.

The results reported by Wittmann (1964) and Anderson et al. (1970) indicate that the cell cultures that are used to detect residual virus infectivity are of great importance; while the latter authors did not observe interference in BHK cells of chemically inactivated FMD-virus particles with infectious particles, the first author found marked interference in primary PK cells but virtually none in primary BK cells. However, the CPE in BHK cells usually was not distinct before a subculture had been made. We observed the same after inoculation of heated virus suspensions onto BTY cell cultures.

In our case milk interferon may also have been responsible for the delayed CPE. Nevertheless, residual virus infectivity could be detected in BTY cell cultures whilst inoculated $\mathrm{PK}_{2}$ cell cultures remained negative (Table 1). The batch of cells used in a particular experiment may also cause variation in the results obtained. In preliminary experiments we did not observe autointerference on one occasion when titrating a primary infected milk sample in $\mathrm{PK}_{2}$ cell cultures 5 days after they had reached confluence but marked autointerference was seen when the test was repeated using cells from the same pig two days earlier.

The complicated interference phenomena described in this report may well account for the erratic results in recovery of infectivity in cell cultures from heated primary infected milk, for example such as those reported by the same group of workers in successive studies (Hyde et al. 1975; Blackwell \& Hyde, 1976; Cunliffe \& Blackwell, 1976).

The observation that no interfering activity could be detected in FMD-virusinfected milk obtained from two intranasally inoculated cows, may be related to the fact that in general virus titres in the milk are much higher after intramammary than after intranasal exposure. Moreover, since primary infection of the mammary gland is unlikely to be a common occurrence in the pathogenesis of FMD (Burrows et al. 1971), the use of infected milk obtained after intramammary inoculation of susceptible cows for studying FMD-virus survival in milk is questionable.

The interference phenomena reported in this study may also explain or partly explain the superiority of the bovine in comparison to cell cultures as a detection system for residual FMD-virus in certain preparations.

The authors wish to thank Dr S. Frenkel for his help in various ways, his staff for providing cell cultures, and $\mathrm{Mr}$ J. Briaire for providing purified virus. 


\section{REFERENCES}

Anderson, E. C., Capstick, P. B., Mowat, G. N. \& Leech, F. B. (1970). In vitro method for the safety testing of foot-and-mouth disease vaccines. Journal of Hygiene 68, 159.

Bachrach, H. L., Breese, S. S., Cartis, J. J., Hess, W. R. \& PatTy, R. E. (1957). Inactivation of foot-and-mouth disease virus by $\mathrm{pH}$ and temperature changes and by formaldehyde. Proceedings of the Society for Experimental Biology and Medicine 95, 147.

Barteling, S. J., Meloen, R. H., Wagenaar, F. \& Gielkens, A. L. J. (1979). Isolation and characterization of trypsin-resistant $\mathrm{O}_{1}$-variants of foot-and-mouth disease virus. Journal of General Virology 43, 383.

Berman, B. \& VILCEK, J. (1974). Cellular binding characteristics of human interferon. Virology 57, 378.

Blackweli, J.H. \& Hyde, J. L. (1976). Effect of heat on foot-and-mouth disease virus (FMDV) in the components of milk from FMDV-infected cows. Journal of Hygiene 77, 77.

BuRrows, R. (1968). Excretion of foot-and-mouth disease virus prior to the development of lesions. Veterinary Record 82, 387.

Burrows, R., Mann, J. A., Greig, A., Chapman, W. G. \& Goodridge, D. (1971). The growth and persistence of foot-and-mouth disease virus in the bovine mammary gland. Journal of Hygiene 69, 307.

CUNLIFFe, H. R. \& BlackWELL, J. H. (1976). Survival of foot-and-mouth disease virus in casein and sodium caseinate produced from the milk of infected cows. Journal of Food Protection 40, 389.

Dawson, P. S. (1970). The involvement of milk in the spread of foot-and-mouth disease: an epidemiological study. Veterinary Record 87, 543.

Dhennin, L. \& Labie, J. (1976). Thermorésistance du virus de la fièvre aphteuse dans le lait de vaches infectées. Bulletin de l'Académie Vétérinaire de France 49, 243.

Frenkel, S. (1964). Modifications de la méthode de culture du virus aphteux selon Frenkel. Valeurs des vaccins selon les données du laboratoire. Bulletin de l'Office international des Epizooties 61, 985.

Gresser, I., Bandu, M. I., Brouty-Boye, D. \& Tovey, M. (1974). Pronounced antiviral activity of human interferon on bovine and porcine cells. Nature 251, 543.

Hedger, R. S. \& Dawson, P. S. (1970). Foot-and-mouth disease virus in milk: An epidemiological study. Veterinary Record 87, 186.

HYDE, J. L., BLACKwELL, J. H. \& CALLIS, J. J. (1975). Effect of pasteurization and evaporation on foot-and-mouth disease virus in whole milk from infected cows. Canadian Journal of comparative Medicine 39, 305.

Kästhi, P. \& Moosbrugger, G. A. (1968). La destruction du virus aphteux par la chaleur dans les produits laitiers. Schweizer Archiv für Tierheilkunde 110, 89.

Lebailly, C. (1920). La virulence du lait dans la fièvre aphteuse. Compte rendu de l'Academie des Sciences, Paris 171, 373.

LeeUW, P. W. DE, BekKum, J. G. van \& Tiessink, J. W. A. (1978). Excretion of foot-andmouth disease virus in oesophageal-pharyngeal fluid and milk of cattle after intranasal infection. Journal of Hygiene 81, 415.

Levine, S. (1964). Effect of actinomycin D and puromycin dihydrochloride on action of interferon. Virology 24, 586.

LockaRT, R. Z. (1973). Criteria for acceptance of a viral inhibitor as an interferon and a general description of the biological properties of known interferons. In: Interferon and Interferon Inducers (ed. N. B. Finter). Amsterdam, London: North Holland.

Matthews, T. H. J., Lawrence, M. K., NaIr, C. D. G. \& TyrRel, D. A. J. (1976). Antiviral activity in milk of possible clinical importance. Lancet ii, 1387.

MoVicar, J. W. \& SUTMolder, P. (1976). Growth of foot-and-mouth disease virus in the upper respiratory tract of non-immunized, vaccinated and recovered cattle after intranasal inoculation. Journal of Hygiene 76, 467.

Nagono, Y. \& MAEHARA, N. (1975). Virus-inhibiting factor or interferon activity on heterologous animal cells. Japanese Journal of Microbiology 19, 447.

Plowright, W. \& FerRIs, R. D. (1961). The preparation of bovine thyroid monolayers for use in virological investigations. Research in Veterinary Science 2, 149. 
Rinaldo, C. R., Isackson, D. W., Overail, J. C., Glasgow, L. A., Brown, T. T., Bistner, S. I., GItLespIe, J. H. \& ScOTT, F. W. (1976). Fetal and adult bovine interferon production during bovine viral diarrhea virus infection. Infection and Immunity 14, 660.

SELleRs, R. F. (1969). Inactivation of foot-and-mouth disease virus in milk. British Veterinary Journal 125, 163.

Stern, J. A., Herlin, M. A. \& Proctor, B. E. (1952). An electronic method for continuous determination of rapid temperature changes in thermal death-time studies. Food Research 17, 460 .

Witmmans, G. (1964). Die Interferenz zwischen inaktiviertem und aktivem Maul-undKlauenseuche-virus in Gewebekulturen. Ihre Bedeutung für die Unschädlichkeitsprüfung von Formalinvakzinen. Zentralblatt für Veterinär Medizin B 11, 135. 